Thorax, 1977, 32, 185-193

\title{
Protective effect of methylprednisolone on ischaemic myocardium assessed by ventricular function
}

\author{
B. L. KRAUSE, M. A. HASSAN, A. B. McMill.AN, AND A. HEDLEY BROWN \\ From the Division of Surgery, Wellington Hospital, Wellington, New Zealand
}

Krause, B. L., Hassan, M. A., McMillan, A. B., and Hedley Brown, A. (1977). Thorax, 32, 185-193. Protective effect of methylprednisolone on ischaemic myocardium assessed by ventricular function. Intracardiac surgical procedures are best carried out when the heart is still and bloodless. This condition, however, produces myocardial cellular damage with loss of contractility and compliance unless some protection can be provided. Myocardial contractility and compliance is best studied by isovolumic ventricular function tests, which were used to evaluate the protective effect of methylprednisolone on the isolated cross-perfused canine heart made ischaemic for 2 hours. Control experiments included 2 hours of ischaemia without methylprednisolone, and 2 hours of continuous normothermic cross-perfusion.

The methylprednisolone-treated hearts had probably significantly better ventricular function after 2 hours of ischaemia than did hearts without the methylprednisolone, while the crossperfused hearts were best overall. This work suggests that methylprednisolone may have a protective effect on the ischaemic myocardium of the intact canine heart.

Protection of the myocardium during cardiac surgery is less than optimal (Maloney and Nelson, 1975). Myocardial cellular damage still occurs to some degree and affects the function of the myocardium after operation.

It is clear that normal myocardial metabolism is almost exclusively aerobic with the chemical energy stored as high energy phosphates, ATP and creatine phosphate (Lundesgaard-Hansen, 1966). The hypoxic heart is more dependent on anaerobic metabolism than normal (Scheuer, 1967). The function of the ischaemic heart is severely depressed (Sarin et al., 1968; Willman and Barner, 1969), and the ultrastructure of the myocardium becomes deranged permanently after about 30 minutes (Buja et al., 1971; Jennings and Ganote, 1972; Balibrea et al., 1975). After the first 6-7 minutes the myocardial creatine phosphate has disappeared (Lundesgaard-Hansen, 1966) and as the ischaemia continues there is glycogen depletion (Scheuer, 1967) and an increasing dependence on lipid metabolism (Moffitt et al., 1970). Residual depression of total high energy nucleotides prevents recovery of normal contractility on reperfusion (Levitsky and Feinberg, 1975).
Hypothermia prevents this disordered metabolism to some extent, reducing the excessive loss of glycogen and creatine phosphate (Hall et al., 1960), so protecting against ischaemia (Mundth et al., 1969; Tyers et al., 1974; MacGregor et al., 1975), and doubling the duration of anoxia without loss of contractility (Enright et al., 1970). But hypothermia may cause oedema of the myocardium and this reduces compliance (Salisbury et al., 1961) and is inferior to continuous normothermic perfusion (Brown et al., 1974). However, continuous perfusion has its hazards also (Shaw et al., 1962; Blackstone et al., 1968; Brown et al., 1969).

It is evident that mechanical and thermal protection alone are insufficient and so biochemical and pharmacological techniques are being investigated (Hickey, 1975).

Mannitol improves perfusion and thus organ function; the hyperosmolality has been shown to improve myocardial contractility (Weisfeldt $e t$ al., 1973). Prostaglandin PGA improves coronary blood flow (Bloor et al., 1975). Glucagon has also been shown to improve myocardial contractility without inducing arrhythmias and independent of digitalis administration (Levine et al., 1969). Beta- 
blocking drugs have a protective effect on the myocardium (Libby et al., 1973b). Propranolol decreases S-T segment elevation, a criterion of ischaemic damage (Maroko et al., 1971). When propranolol is combined with glucose-potassiuminsulin infusion, an increased survival time from asphyxia has been reported, the probable mechanism being a slowing of ATP depletion (Wildenthal et al., 1973). Retrograde insufflation of gaseous oxygen into the coronary sinus has been shown to preserve ventricular function better than ischaemia (Brown et al., 1972c) while ATPase inhibition and provision of high energy phosphates showed no significant advantage over simple hypothermia (Brown et al., 1972b).

Corticosteroids were reported to have a beneficial effect in limiting the size of experimentally produced myocardial infarcts (Johnson et al.. 1953), but this was not confirmed by others (Hepper et al., 1955). Further investigations showed that glucocorticoids, as distinct from mineralocorticoids (Lefer and Martin, 1969), have a beneficial effect on the heart, and early trials on experimental canine infarctions and in 38 clinical cases showed an increased vascularity and a decreased mortality rate (Gerisch and Compeau, 1958). More recent experiments have shown a reduction in size or a decrease in spread of infarcts after administra. tion of hydrocortisone (Libby et al., 1973a), dexamethasone (Spath and Lefer, 1975), and methylprednisolone (Spath et al., 1974); all three trials used elevation of S-T segments and creatine phosphokinase (CPK) levels as criteria of ischaemia. Clinical trials also differ in their conclusions on the benefit of high doses of hydrocortisone in infarction (Dall and Peel, 1963; Scottish Society of Physicians Scientific Subcommittee, 1964; Barzilai et al., 1972) and shock (Lefer and Martin, 1969; Lefer, 1974).

The mechanisms of the reported beneficial effects of corticosteroids on the heart are still largely unknown. Increases in cardiac output (Sambhi et al., 1965) have suggested an inotropic effect, but even though corticosteroids appear structurally related to known inotropic agents this has not been confirmed (Spath et al., 1973; Lefer, 1974). Reports of systemic (Dietzman et al., 1970; Dietzman et al., 1975) and coronary (Hinshaw et al., 1974) vasodilatation appear to show an action on blood vessels, and although there are reports to the contrary (Spath and Lefer, 1975), there may be an inhibition of catecholamineinduced vasoconstriction (Altura et al., 1974). An increase in myocardial contractility has been produced-directly (Carter and Thomas, 1970), by increased coronary perfusion (Hinshaw et al.,

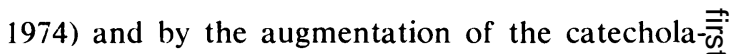
mine response to stress (Replogle et al., 1962Alexander et al., 1969), the effect of the steroidso being absent in adrenalectomised dogs (Tecklen-क berg et al., 1973). Other studies, however, haved shown no potentiation or sensitisation to catecholamines by corticosteroids (Lefer, 1974).

The protective effect of corticosteroids is said $\overrightarrow{0}$ to arise from the 'stabilisation of membrane structures', particularly lysosomes, which may release hydrolytic enzymes and damage the celle (Weissman and Thomas, 1964; Brachfeld, $1969 \underset{\dot{w}}{\times}$ Shannon and Courtice, 1975). This has been re ported as a mechanism of myocardial necrosis (Brachfeld and Gemba, 1965). The stabilisation ofo lysosomal membranes would explain the reductiono of pathological increase of known lysosomaP enzymes in the plasma and the reduction of necrosis by steroid treatment of myocardial in farction (Spath and Lefer, 1975), pancreatic ischaemia (Ferguson et al., 1972), hepaticy ischaemia (Figueroa and Santiago-Delpín, 1975): and haemorrhagic shock (Spath et al., 1973) Recently, however, this theory also has beens challenged (Persellin and Ku, 1974; Wiener et al. 1975).

Whatever the mechanism, a protective effec $\mathbb{B}$ against ischaemia probably exists and should guard the myocardium against ischaemia arising during cardiopulmonary bypass. This protective effect has been reported, enhancing recovery afteㄹ. anoxia in the papillary muscle (Jewitt et al., 1972) and reducing the compliance deficit of the lef ventricle of an isolated heart (Toyama and Reis 1975) and the contractility deficit of in-situ veno tricles (Busuttil et al., 1975). These preparations. involve cardiopulmonary bypass with the heart iro situ; the steroid may be protecting against dele $₹$ terious effects of whole-body perfusion and extra윽 corporeal oxygenation (Brown et al., 1972a). SQ far there has been no report of this protective. effect on contractility in the intact isolated cross perfused heart.

\section{Form of the investigation}

Isolated perfused hearts are stable when crosso perfused (Londe, 1969) and can therefore be usec in experiments determining myocardial con $\stackrel{?}{+}$ tractility. Although no preparation is perfect, be=0 cause the function of isolated papillary muscle an $\vec{\Phi}$ the isolated heart varies according to pre-load after-load, and heart rate (Jochim and Behrendtकि 1975), the isovolumic tests carried out on isolate hearts are closer to the clinical situation.

Isovolumic ventricular function tests carried ou 
by means of a balloon fixed in the ventricle were performed before and after a 2-hour period of uninterrupted normothermic cross-perfusion (group 1); ischaemia (group 2); and ischaemia with methylprednisolone given before the ischaemic period (group 3). Variables measured included peak systolic pressure, end-diastolic pressure, rate of rise of pressure $(\mathrm{dp} / \mathrm{dt})$, and the pressure at which $\mathrm{dp} / \mathrm{dt}$ was maximal. Regression slopes of end-diastolic volume, peak systolic pressure, and peak $\mathrm{dp} / \mathrm{dt}$ were calculated against end-diastolic pressure. These values, representing contractile force, velocity, and compliance (Brown et al., 1977), could then be compared at a standard enddiastolic pressure of $1.33 \mathrm{kPa}(10 \mathrm{mmHg})$, expressing all values after the experimental period relative to those before it.

\section{Method}

Mongrel dogs, weighing from 14 to $32 \mathrm{~kg}$, were premedicated with acetylpromazine, 5-10 mg intramuscularly, and after 15 minutes were anaesthetised with $30-40 \mathrm{mg} / \mathrm{kg}$ sodium pentobarbital, intubated, and ventilated with $60 / 40 \mathrm{~N}_{2} \mathrm{O} / \mathrm{O}_{2}$ from a respirator. The chest was opened by a median sternotomy and the heart exposed by excision of the pericardium. Heparin, $5 \mathrm{mg} / \mathrm{kg}$, was administered intravenously; the aortic root was cannulated for monitoring and perfusion via the subclavian arteries and the right ventricle via the right atrial appendage. The second dog was similarly premedicated, anaesthetised, intubated, ventilated, and heparinised, and its femoral arteries and vein were cannulated for bypass and pressure monitoring. The arterial cannula was connected to a calibrated pump which led to the aortic cannula of the experimental heart and a pressure-limiting side arm which overflowed when $13.30 \mathrm{kPa}(100$ $\mathrm{mmHg}$ ) was exceeded. The venous cannula of the second dog was connected to the right heart cannula of the experimental heart and to a funnel in which the heart was to lie and into which the arterial overflow was fed. The circuit was primed with $5 \%$ dextrose in distilled water which was exchanged with the blood of the support dog. The cavae of the experimental heart were tied and, while the heart emptied itself, the aorta below the subclavian artery, the brachiocephalic artery, and the pulmonary artery were then tied in that order. The isolated heart's circulation was begun and its venous cannula unclamped. The heart was thus perfused continuously with minimal mixing of the blood of the two dogs. The heart was fibrillated electrically, its attachments divided, and the free heart placed in the funnel. A fine Latex balloon was held in the left ventricle by a pursestring suture around the free edge of the mitral valve, which was tightened around a flange connecting the balloon to pressure transducers and a graduated syringe. Measured fluid was then placed in the balloon to raise the end-diastolic pressure above $0.665 \mathrm{kPa}(5 \mathrm{mmHg})$ when electrical defibrillation was performed. The heart was paced at a rate of 100 beats/min if necessary and ECG leads and a temperature probe were attached to the right heart (Fig. 1). Fluid was added in $2.5 \mathrm{ml}$ increments to raise the end-diastolic pressure in the ventricle from $0-1.33 \mathrm{kPa}(0-10 \mathrm{mmHg})$, recording a few beats at each volume. The experimental technique to be applied to a particular dog was chosen at random. This was: group 1, continuous normothermic cross perfusion for 2 hours; group 2, 2 hours of ischaemia attained by terminating pump action, thus stopping perfusion of the heart; group 3, ischaemia attained similarly with methylprednisolone sodium succinate, $30 \mathrm{mg} / \mathrm{kg}$, given slowly intravenously into the support dog before terminating perfusion of the heart, with time allowed for circulation to the isolated heart. In all cases there was sufficient fluid left in the balloon to keep the end-diastolic pressure above zero.

After the 2 hours, in groups 2 and 3, the hearts were again perfused, starting at very low perfusion pressures and gradually increasing to levels similar to the initial ones. Time was allowed for these hearts to regain as much function as possible, and once they were stable a further series of ventricular function tests were recorded in all three groups. After the recordings had been taken perfusion was stopped, and the ventricle was dissected from the rest of the heart; its weight and volume by displacement were then measured as well as the weight of the dog from which it came.

\section{Results}

PEAK SYSTOLIC PRESSURE

The hearts maintained by continuous normothermic cross-perfusion developed a higher pressure relative to the initial level than those of the other two groups. The hearts given the methylprednisolone before ischaemic arrest showed a probably significantly higher force than those not given the methylprednisolone. The difference between the continuous normothermic cross-perfused hearts and the ischaemic hearts with and without the methylprednisolone was significant (Table 1; Fig. 2). 


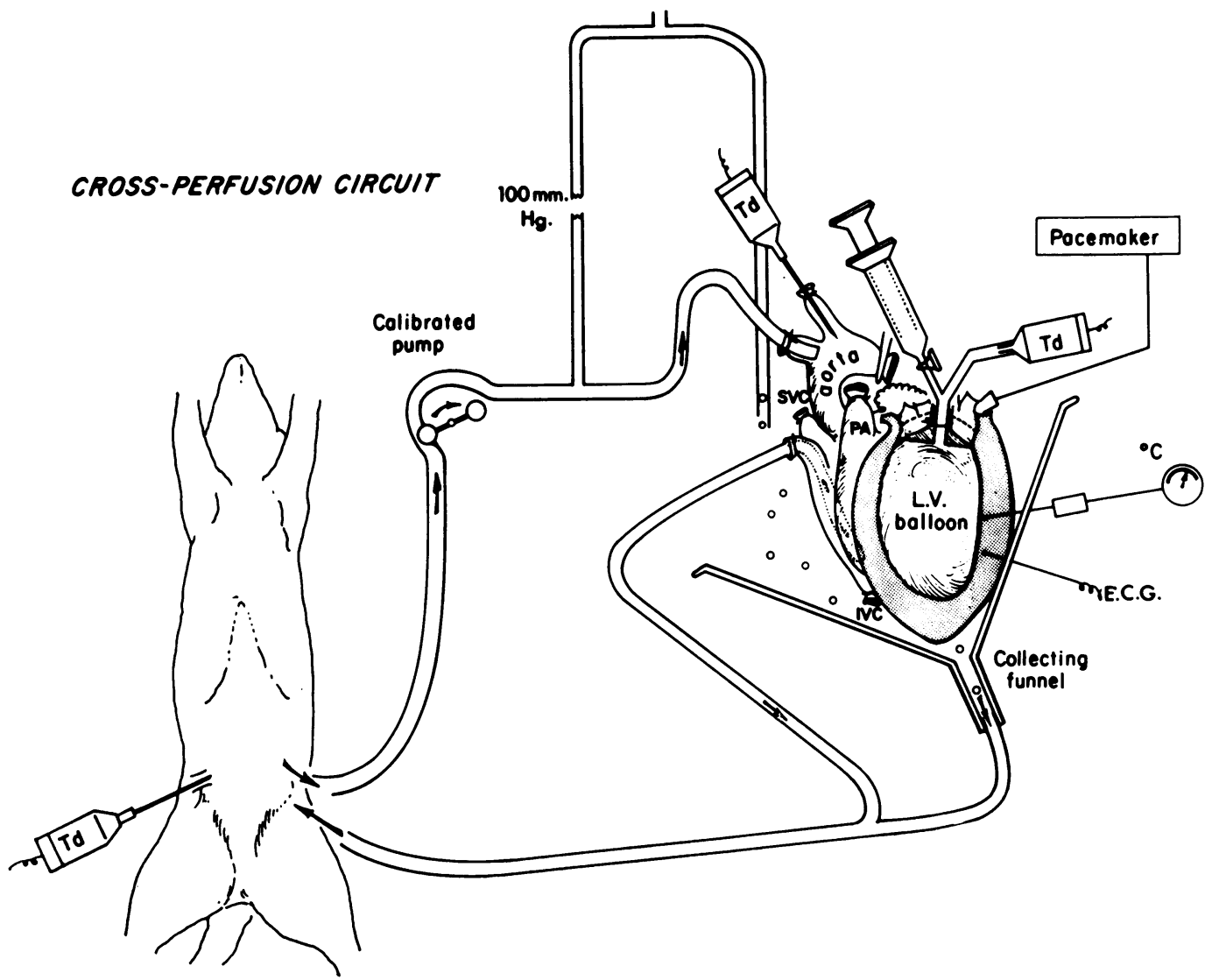

Fig. $1 A$ diagram of the experimental layout: $T d=$ pressure transducer; $E C G=$ electrocardiogram; $S V C=$ superior vena cava; $I V C=$ inferior vena cava; $P A=$ pulmonary artery.

Table 1 Peak systolic pressure at end-diastolic pressure of $1.33 \mathrm{kPa}(10 \mathrm{mmHg})$ after 2 hours of preservation, expressed as percentages of initial values

\begin{tabular}{|c|c|c|c|c|c|c|}
\hline \multirow{2}{*}{ Group } & \multirow{2}{*}{ No. } & \multirow{2}{*}{ Mean } & \multirow{2}{*}{$S E$} & \multicolumn{3}{|c|}{$\mathbf{P}$ values } \\
\hline & & & & 1 & 2 & 3 \\
\hline $\begin{array}{l}1 \text { Continuous } \\
\text { normothermic } \\
\text { perfusion } \\
2 \text { Ischaemia } \\
3 \text { Ischaemia with } \\
\text { methylprednisolone }\end{array}$ & $\begin{array}{l}19 \\
10 \\
13\end{array}$ & $\begin{array}{r}137 \\
35 \\
\\
48\end{array}$ & $\begin{array}{r}17 \cdot 665 \\
4 \cdot 7434 \\
3 \cdot 8829\end{array}$ & & $<0.001$ & $\begin{array}{l}<0.001 \\
<0.05\end{array}$ \\
\hline
\end{tabular}

The group, number of animals, mean of this variable, and standard error of the mean for each of the three groups is shown against a table of the probability $(P)$ that the apparent superiority of continuous normothermic perfusion over ischaemia or ischaemia with methylprednisolone prior to ischaemia is due to chance.

\section{CONTRACTILE VELOCITY}

The rate of rise of pressure at an end-diastolic pressure of $1.33 \mathrm{kPa}(10 \mathrm{mmHg})$ at the end of the 2 -hour period relative to the initial values was highest in the continuously perfused hearts (group 1) followed by the hearts treated with methylpred nisolone (group 3) and the ischaemic hearts (group 2) respectively. The differences between the constantly perfused hearts and the other two groups was significant (Table 2; Fig. 2).

\section{COMPLIANCE OF THE VENTRICLES}

The difference in volume in the ventricle between the end-diastolic pressures of $0-1.33 \mathrm{kPa}(0-19$ $\mathrm{mmHg}$ ) at the end of the experimental period of 2 hours was highest in the continuously cross perfused hearts (group 1), next highest in the methylprednisolone-treated hearts (group 3), and lowest in the ischaemic hearts (group 2). The differences between group 1 and the other tw\& groups were significant (Table 3; Fig. 2).

OEDEMA OF THE MYOCARDIUM

The oedema of the myocardium was calculated 


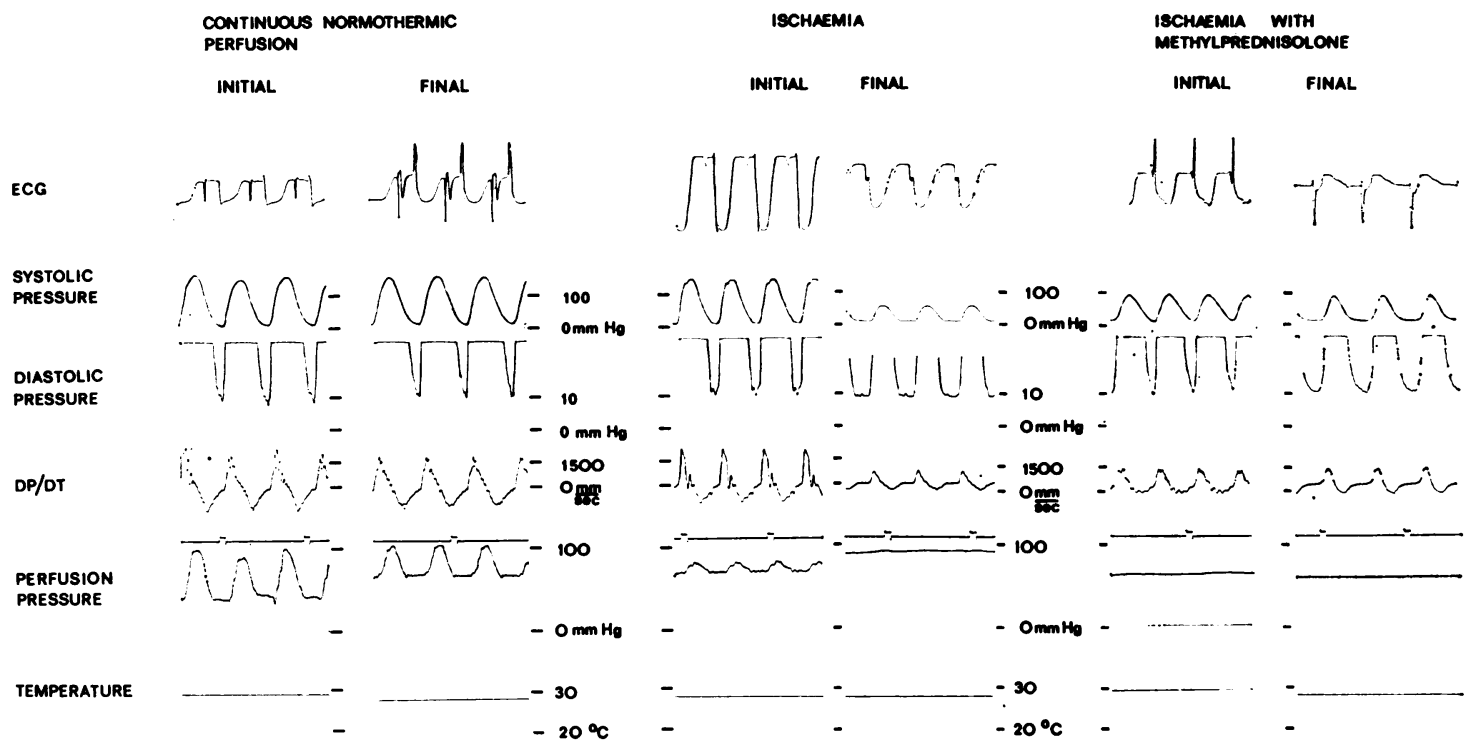

Fig. 2 Initial and final traces as representations of the three experimental groups.

Table 2 Contractile velocity at end-diastolic pressure of $1.33 \mathrm{kPa}(10 \mathrm{mmHg})$ after 2 hours of preservation, expressed as percentages of initial values

\begin{tabular}{|c|c|c|c|c|c|c|}
\hline \multirow{2}{*}{ Group } & \multirow{2}{*}{ No. } & \multirow{2}{*}{ Mean } & \multirow{2}{*}{$S E$} & \multicolumn{3}{|c|}{ P values } \\
\hline & & & & 1 & 2 & 3 \\
\hline $\begin{array}{l}1 \text { Continuous } \\
\text { normothermic } \\
\text { perfusion } \\
2 \text { Ischaemia } \\
3 \text { Ischaemia with } \\
\text { Methylprednisolone }\end{array}$ & $\begin{array}{l}19 \\
10 \\
13\end{array}$ & $\begin{array}{r}143 \\
32 \\
39\end{array}$ & $\begin{array}{r}20.42 \\
7.589 \\
5.269\end{array}$ & & $<0.001$ & $\begin{array}{l}<0.001 \\
\text { NS }\end{array}$ \\
\hline
\end{tabular}

As in Table 1, the P-values representing the probability that the difference between continuous normothermic perfusion and the other techniques was due to chance. NS, difference between the ischaemic groups is not significant.

a ratio of the weight of the animal to the weight of the dissected left ventricle after the 2-hour experimental period. No difference reached statistical significance (Table 4).

\section{Discussion}

These experiments have shown that methylprednisolone administered before an ischaemic insult to the myocardium probably improves recovery of ventricular function as measured by peak systolic pressure after 2 hours of preservation. The validity of these results must be considered in the light of the experimental preparation and any possible clinical applications they might have.
Table 3 Compliance of the ventricles after the experimental period, expressed as percentage of initial values

\begin{tabular}{|c|c|c|c|c|c|c|}
\hline \multirow{2}{*}{ Group } & \multirow{2}{*}{ No. } & \multirow{2}{*}{ Mean } & \multirow{2}{*}{$S E$} & \multicolumn{3}{|c|}{ P values } \\
\hline & & & & 1 & 2 & 3 \\
\hline $\begin{array}{l}1 \text { Continuous } \\
\text { normothermic } \\
\text { perfusion } \\
2 \text { Ischaemia } \\
3 \text { Ischaemia with } \\
\text { methylprednisolone }\end{array}$ & $\begin{array}{l}19 \\
10 \\
13\end{array}$ & $\begin{array}{r}109 \cdot 5 \\
57 \cdot 4 \\
69 \cdot 0\end{array}$ & $\begin{array}{c}10.989 \\
8.1903 \\
10.76\end{array}$ & & 0.0053 & $\begin{array}{l}0.023 \\
\text { NS }\end{array}$ \\
\hline
\end{tabular}

As for Table 2.

Table 4 Oedema of the myocardium, expressed as weight of LV/kilogram of animal

\begin{tabular}{|c|c|c|c|c|c|c|}
\hline \multirow{2}{*}{ Group } & \multirow{2}{*}{ No. } & \multirow{2}{*}{ Mean } & \multirow{2}{*}{$S E$} & \multicolumn{3}{|c|}{ P values } \\
\hline & & & & 1 & 2 & 3 \\
\hline $\begin{array}{l}1 \text { Continuous } \\
\text { normothermic } \\
\text { perfusion } \\
2 \text { Ischaemia } \\
3 \text { Ischaemia with } \\
\text { methylprednisolone }\end{array}$ & $\begin{array}{r}19 \\
10 \\
13\end{array}$ & $\begin{array}{l}5 \cdot 7756 \\
5 \cdot 4 \\
5 \cdot 579\end{array}$ & $\begin{array}{l}0.503 \\
0.221 \\
0.329\end{array}$ & & NS & $\begin{array}{l}\text { NS } \\
\text { NS }\end{array}$ \\
\hline
\end{tabular}

There are no significant differences between the groups for this variable.

\section{THE PREPARATION}

Isolated perfused hearts are satisfactory preparations for assessing ventricular function (Blackstone et al., 1968; Londe, 1969) and, when crossperfused, are free from the inherent deterioration 
of oxygenator preparations. Although non-invasive methods of assessing myocardial contractility have been devised for use in patients (Levitsky and Merchant, 1973; Hardason et al., 1974), isovolumic function tests permit a more satisfactory estimate of ventricular function (Brown et al., 1969). Isolated papillary muscle preparations are also used to estimate myocardial contractility, and although the function of these preparations like that of intact isolated hearts varies with pre-load, afterload, and heart rate (Mason et al., 1971; Jochim and Behrendt, 1975), further assumptions concerning the geometry of the ventricle (Levitsky and Merchant, 1973) are necessary to extrapolate data obtained from the experiments (Sonnenblick, 1962; Levine and Britman, 1964). The isolated heart does not have this problem and is therefore more suitable for ventricular function tests.

Myocardial contractility may be approached and investigated in several ways (Levitsky and Merchant, 1973). Ventricular end-diastolic pressure, systolic pressure, and stroke volume give only indirect information (Braunwald et al., 1967), while wall tension, stress, and contractile velocity, although difficult to calculate, give a theoretically better estimation of myocardial contractility. The direct measurements of systolic pressure, rate of rise of pressure, and diastolic pressure/volume relationships as indices of contractile force, velocity, and compliance are as efficient in discriminating excellence of myocardial preservation as are the derived data (Brown et al., 1977).

The regime of administration of the methylprednisolone was based on previous work using the steroid (Blinderman et al., 1962; Jewitt et al., 1972; Dietzman et al., 1975). It has been shown that the vehicles of some preparations of methylprednisolone have a toxic effect on cardiac function (Vargish et al., 1974) but the solution used in these experiments (Solumedrol, Upjohn Ltd) did not contain the chemical involved. It has also been shown that sodium succinate per se has no effect on cardiac index, peripheral resistance, or oxygen consumption of the myocardium (Dietzman et al., 1973). To affect the amount of ischaemic damage the steroid must be given before the onset of ischaemia (Spath et al., 1974), which was the procedure used in these experiments.

\section{CLINICAL APPLICATIONS}

Depressed myocardial function is of ten observed after open-heart surgery and is due mainly to ischaemic injury to the myocardium (Cooper, 1975; Maloney et al., 1975). After cardiopulmonary bypass patients may show a 'low output syndrome' as a result of depressed ventricular function (Dietzman et al., 1969; Buckberg et al. $\overrightarrow{\overrightarrow{\mathrm{S}}}$ 1975). Increased peripheral resistance also occurs after operations, and this is of special importances after cardiac operations as it adds further stress top the already damaged myocardium (Matthews $e$ \& al., 1974). This means that the demand upon the heart may be beyond its reserves (Wisheart, 1975) Myocardial oedema may also play a part in the cycle of further myocardial depression by impair $\overline{-}$ ing oxygen diffusion to the cell (Wisheart, 1975 and by decreasing the compliance of the hear (Cross et al., 1961; Salisbury et al., 1961).

Methylprednisolone has already been shown tô affect the postischaemic function of the myocar ${ }_{2}^{N}$ dium in terms of tension development (Jewitt $e$ e $a l ., 1972)$ by reducing the compliance deficit that normally accompanies ischaemic arrest (Toyama and Reis, 1975) and the contractility deficit of in $\rightarrow$ situ ventricles (Busuttil et al., 1975). The steroide. has been shown to have a beneficial effect in re ducing the added stress of a peripheral vasocon striction if it is given before the onset of bypass (Replogle et al., 1966). The results of the experi응 ments reported here add evidence to the post ischaemic protection of the myocardium and to the observed vasodilator effects reported by otherö (Dietzman et al., 1970; Dietzman et al., 1975).

The determination of the mechanism of action of methylprednisolone on the myocardium was no 3 one of the objects of these experiments. However it seems clear from published reports that there iș. some effect on membranes. Myocardial con tractility depends on the integrity of membraneso of cells and subcellular organelles as well as on ATPase and calcium (Brown et al., 1969). Anyog protection that can be afforded to stop dysfunction of the cell by lysosomal damage would therefores improve ventricular contractility after injury. $\operatorname{Re} \xi$ cent evidence supports the 'membrane stabilisa윽 tion' theory, as labelled steroid does localise in lysosomes and lysosomal membranes (Wilson, 1974). The effect of the steroid is seen in the alter ation of permeability characteristics of the lyso- $\Omega$ somal membrane (Ignarro, 1972; Goldstein, 1975). 0

Methylprednisolone has been shown here tow promise better protection of the myocardiumo during open-heart surgery.

This work was supported by the New Zealand? Medical Research Council and the Wellingtono Medical Research Foundation. One of us (BLK) was funded by an MRC Summer Studentship. We also acknowledge the assistance of Mrs Robyn歫 Bowie and Messrs C. Wilson, S. Doran, and W.Armstrong, and Upjohn Itd for providing the Solumedrol. 


\section{References}

Alexander, R. W., Kuzela, L., Kerth, W. J., Harrison, J., and Gerbode, F. (1969). Adrenal catecholamine and cortisol secretion during extracorporeal circulation in dogs. Journal of Thoracic and Cardiovascular Surgery, 58, 251-258.

Altura, B. M., Altura, B. T., and Hershey, S. G. (1974). Pharmacodynamic actions of corticosteroids on the microcirculation and vascular smooth muscle. In Steroids and Shock, edited by T. M. Glenn, pp. 67-88. University Park Press, Baltimore.

Balibrea, J. L., Bullon, A., de la Fuente, A., de la F. Alarcon, A.. Farinas, J., Collantes, P., Gil, M., Gombau, M., Morales, R., and Sanchez, F. (1975). Myocardial ultrastructural changes during extracorporeal circulation with anoxic cardiac arrest and its prevention by coronary perfusion. Thorax, 30, 371-381.

Barzilai, D., Plavnick, J., Hazani, A., Einath, R., Kleinhaus, N., and Kanter, Y. (1972). Use of hydrocortisone in the treatment of acute myocardial infarction. Chest, 61, 488-491.

Blackstone, E. H., Evans, R. H., Eckner, F. A. O., Drake, A., and Moulder, P. V. (1968). Perfusioninduced myocardial injury. Journal of Thoracic and Cardiovascular Surgery, 56, 689-698.

Blinderman, E. E., Graf, C. J., and Fitzpatrick, T. (1962). Basic studies in cerebral edema; its control by a corticosteroid (Solu-medrol). Journal of Neurosurgery, 19, 319-324.

Bloor, C. M., White, F. C., and Sobel, B. E. (1975). Coronary and systemic haemodynamic effects of prostaglandins in the unanaesthetized dog. Cardiovascular Research, 7, 156-166.

Brachfeld, N. (1969). Maintenance of cell viability. Circulation, 39-40, Supplement, 4, 202-219.

Brachfeld, N. and Gemba T. (1965). Mechanisms of myocardial cell death: release of lysosomal hydrolases after ischemia (Abstract). Clinical Research, 13, 524.

Braunwald, E., Ross, J., Jr., and Sonnenblick, E. H. (1967). Mechanisms of contraction of the normal and failing heart, III. New England Journal of Medicine, 277, 910-920.

Brown, A. H., Braimbridge, M. V., Darracott, S., Chayen, J., and Kasap, H. (1974). An experimental evaluation of continuous normothermic, intermittent hypothermic, and intermittent normothermic coronary perfusion. Thorax, 29, 38-50.

Brown, A. H., Braimbridge, M. V., Niles, N. R., and Austen, W. G. (1977). Assessment of the heart by histochemistry and birefringence compared with ventricular function. Journal of Cardiovascular Surgery. (In press.)

Brown, A. H., Braimbridge, M. V., Niles, N. R., Gerbode, F., and Aguilar, M. J. (1969). The effect of excessively high perfusion pressures on the histology, histochemistry, birefringence, and function of the myocardium. Journal of Thoracic and Cardiovascular Surgery, 58, 655-663.

Brown, A. H., Niles, N. R., Braimbridge, M. V., and
Austen, W. G. (1972a). Damage to isolated hearts by oxygenators. Annals of Thoracic Surgery, 13, 575-588.

Brown, A. H., Niles, N. R., Braimbridge, M. V., and Austen, W. G. (1972b). The combination of adenosine-triphosphatase inhibition and provision of high-energy phosphates for the preservation of unperfused myocardium, assessed by ventricular function, histochemistry and birefringence. Journal of Cardiovascular Surgery, 13, 602-616.

Brown, A. H., Niles, N. R., Braimbridge, M. V., and Austen, W. G. (1972c). Retrograde insufflation of gaseous oxygen into the coronary sinus as a means of myocardial maintenance. Archives of Surgery, $105,622-627$.

Buckberg, G. D., Olinger, G. N., Mulder, D. G., and Maloney, J. V. Jr. (1975). Depressed postoperative cardiac performance. Journal of Thoracic and Cardiovascular Surgery, 70, 974-988.

Buja, L. M., Levitsky, S., Ferrans, V. J., Souther, S. G., Roberts, W. C., and Morrow, A. G. (1971). Acute and chronic effects of normothermic anoxia on canine hearts. Circulation, 43, Supplement, 1, 44-50.

Busuttil, R. W., George, W. J., and Hewitt, R. L. (1975). Protective effect of methylprednisolone on the heart during ischemic arrest. Journal of Thoracic and Cardiovascular Surgery, 70, 955-965.

Carter, J. W. and Thomas, C. S., Jr. (1970). The circulatory response to pharmacological levels of hydrocortisone. Journal of Surgical Research, 10, 437-442.

Cooper, D. K. C. (1975). Observations on ischaemic contracture of the heart (stone heart). Cardiovascular Research, 9, 246-248.

Cross, C. E.. Rieben, P. A., and Salisbury, P. F. (1961). Influence of coronary perfusion and myocardial edema on pressure-volume diagram of left ventricle. American Journal of Physiology, 201, 102-108.

Dall, J. L. C. and Peel, A. A. F. (1963). A trial of hydrocortisone in acute myocardial infarction (Letter). Lancet, 2, 1097-1098.

Dietzman, R. H., Castaneda, A. R., Lillehei, C. W., Ersek, R. A., Motsay, G. J., and Lillehei, R. C. (1970). Corticosteroids as effective vasodilators in the treatment of low output syndrome. Chest, 57, 440-453.

Dietzman, R. H., Ersek, R. A., Lillehei, C. W., Castaneda, A. R., and Lillehei, R. C. (1969). Low output syndrome: recognition and treatment. Journal of Thoracic and Cardiovascular Surgery, 57, 138-150.

Dietzman, R. H., Lunseth, J. B., Goott, B., and Berger, E. C. (1975). The use of methylprednisolone during cardiopulmonary bypass. Journal of Thoracic and Cardiovascular Surgery, 69, 870-873.

Dietzman, R. H., Shatney, C. H., and Lillehei, R. C. (1973). Comparative effects of the salt radical associated with corticosteroids in cardiogenic shock (Abstract). Circulation, 47-48, Supplement 4, 108.

Enright, L. P., Staroscik, R. N., and Reis, R. L. 
(1970). Left ventricular function after occlusion of the ascending aorta: assessments of various methods for myocardial protection. Journal of Thoracic and Cardiovascular Surgery, 60, 737-745.

Ferguson, W. W., Glenn, T. M., and Lefer, A. M. (1972). Mechanisms of production of circulatory shock factors in isolated perfused pancreas. American Journal of Physiology, 222, 450-457.

Figueroa, I. and Santiago-Delpín, E. A. (1975). Steroid protection of the liver during experimental ischemia. Surgery, Gynecology and Obstetrics, 140, 368-370.

Gerisch, R. A. and Compeau, L. (1958). Treatment of acute myocardial infarction in man with cortisone. American Journal of Cardiology, 1, 535-536.

Goldstein, I. M. (1975). Effect of steroids on lysosomes. Transplantation Proceedings, 7, 21-24.

Hall, D. P., Singal, S. A., Moretz, W. H., Brackney, E. L., Butler, W. F.. Maloy, W. C., Bernstein, V., and Ellison, R. G. (1960). Myocardial metabolism during elective cardiac arrest determined by biochemical analysis of multiple cardiac biopsies. Surgical Forum, 10, 540-547.

Hardason, T.. Ziady, G. M., and Khattri, H. N. (1974). Assessment of left ventricular function following coronary bypass surgery; a non-invasive study. Thorax, 29, 359-365.

Hepper, N. G., Pruitt, R. D., Donald, D. E., and Edwards, J. E. (1955). The effect of cortisone on experimentally produced myocardial infarcts. Circulation, 11, 742-748.

Hickey, P. A. (1975). Prevention of intraoperative myocardial injury by pretreatment with pharmacological agents. Annals of Thoracic Surgery, 20, 101-105.

Hinshaw, L. B., Archer, L. T., Black, M. R., and Greenfield, L. J. (1974). Effects of methylprednisolone sodium succinate on myocardial performance, hemodynamics and metabolism in normal and failing hearts. In Steroids and Shock, edited by T. M. Glenn, pp. 253-273. University Park Press, Baltimore.

Ignarro, L. J. (1972). Lysosome membrane stabilization in-vivo; effects of steroidal and non-steroidal anti-inflammatory drugs on the integrity of rat liver lysosomes. Journal of Pharmacology and Experimental Therapeutics, 182, 179-188.

Jennings, R. B. and Ganote. C. E. (1972). Ultrastructural changes in acute myocardial ischaemia. In Effect of Acute Ischaemia on Myocardial Function, edited by M. F. Oliver, D. G. Julian, and K. W. Donald, pp. 50-74. Churchill Livingstone, Edinburgh.

Jewitt. D. E., Skelton, C. L., and Sonnenblick, E. H. (1972). Salutary effect of methyl prednisolone (MP) on the viability of heart muscle exposed to anoxia (Abstract). Circulation, 45-46, Supplement 2,121 .

Jochim, K. E. and Behrendt, D. M. (1975). Evaluation of myocardial function. Annals of Thoracic Surgery, 20, 30-38.

Johnson. A. S., Scheinberg. S. R., Gerisch, R. A.,

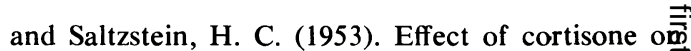
the size of experimentally produced myocardia infarcts. Circulation, 7, 224-228.

Lefer, A. M. (1974). Myocardial action of corticon steroids. In Steroids and Shock, edited by T. M. Glenn, pp. 53-66. University Park Press, Baltimore?

Lefer, A. M. and Martin, J. (1969). Mechanisms of the protective effect of corticosteroids in hemorrhagic shock. American Journal of Physiology, 216. 314-320.

Levine, H. J. and Britman, N. A. (1964). Force velocity relation in the intact dog heart. Journal of Clinical Investigation, 43, 1383-1396.

Levine, M. J., Cole, A. T., McConn, R., Del Guerciou L. R. M., and Siegel, J. H. (1969). Effects off glucagon infusion on cardiovascular function i $\overrightarrow{00}$ critically ill surgical patients. Surgical Forum, 20\% 166-169.

Levitsky, S. and Feinberg, H. (1975). Biochemicat changes of ischemia. Annals of Thoracic Surger 20, 21-29.

Levitsky, S. and Merchant, F. J. (1973). Non-invasive methods of measuring myocardial contractility Surgery Annual, 5, 265-281.

Libby, P., Maroko, P. R., Bloor, C. M., Sobel, B. E. and Braunwald, E. (1973a). Reduction of experis mental myocardial infarct size by corticosteroi administration. Journal of Clinical Investigation 52, 599-607.

Libby, P., Maroko, P. R., Covell, J. W., Malloch? C. I., Ross, J., Jr., and Braunwald, E. (1973b) Effect of practolol on the extent of myocardia ischaemic injury after experimental coronary occlusion and its effects on ventricular function i the normal and ischaemic heart. Cardiovascula Research, 7, 167-173.

Londe, S. P. (1969). The isolated perfused heart: it physiology and metabolism. Surgical Forum, 200 159-161.

Lundesgaard-Hansen, P. (1966). Surgical aspects of cardiac metabolism. Surgery, Gynecology and Obstetrics, 122, 1095-1108.

MacGregor, D. C., Wilson, G. J., Tanaka, S., Holness? D. E., Lixfeld, W., Silver, M. D., Rubis, L. J. Goldstein, W., and Gunstensen, J. (1975). Ischemie contracture of the left ventricle. Journal of Thoraci and Cardiovascular Surgery, 70, 945-954.

Maloney, J. V. Jr. Cooper, N., Mulder, D. G., and Buckberg, G. D. (1975). Depressed cardiac per formance after mitral valve replacement. Circula ${ }^{\mathrm{C}}$ tion. 52, Supplement 1, 3-8.

Maloney, J. V., Jr. and Nelson, R. L. (1975). Myoo cardial preservation during cardiopulmonary bypass. Journal of Thoracic and Cardiovascula? Surgery, 70, 1040-1050.

Maroko, P. R., Kjekshus, J. K., Sobel, B. E.? Watanabe, T., Covell, J. W., Ross, J., Jr., anब Braunwald, E. (1971). Factors influencing infarc है size following experimental coronary artery occlusions. Circulation, 43, 67-82.

Mason, D. T., Braunwald, E., Covell, J. W., Sonnen? blick, E. H., and Ross, J., Jr. (1971). Assessmento 
of cardiac contractility: the relation between the rate of pressure rise and ventricular pressure during isovolumic systole. Circulation, 44, 47-58.

Matthews, H. R., Meade, J. B., and Evans, C. C. (1974). Significance of prolonged peripheral vasoconstriction after open-heart surgery. Thorax, 29, 343-348.

Moffitt, E. A., Rosevear, J. W., Molnar, G. D., and McGoon, D. C. (1970). Myocardial metabolism in open-heart surgery. Journal of Thoracic and Cardiovascular Surgery, 59, 691-706.

Mundth, E. D., Sokol, D. M., Levine, F. H., and Austen, W. G. (1969). Preservation of myocardial function during extended periods of coronary ischemia. Surgical Forum, 20, 176-179.

Persellin, R. H. and $\mathrm{Ku}, \mathrm{L}$. C. (1974). Effects of steroid hormones on human polymorphonuclear leukocyte lysosomes. Journal of Clinical Investigation, 54, 919-925.

Replogle, R. L., Gazzaniga, A. B., and Gross, R. E. (1966). Use of corticosteroids during cardiopulmonary bypass: possible lysosome stabilization. Circulation, 33-34, Supplement 1, 86-92.

Replogle, R. L., Levy, M., deWall, R. A., and Lillehei, R. C. (1962). Catecholamine and serotonin response to cardiopulmonary bypass. Journal of Thoracic and Cardiovascular Surgery, 44, 638-648.

Salisbury, P. F., Cross, C. E., Katsuhara, K., and Rieben, P. A. (1961). Factors which initiate or influence edema in the isolated dog's heart. Circulation Research, 9, 601-606.

Sambhi, M. P., Weil, M. H., and Udhoji, V. N. (1965). Acute pharmacodynamic effects of glucocorticoids. Circulation, 31, 523-530.

Sarin, C. L., Hall, R. W., and Ross, D. N. (1968). Effects of extracorporeal circulation on left ventricular function with and without anoxic arrest. Journal of Thoracic and Cardiovascular Surgery, 56, 395-400.

Scheuer, J. (1967). Myocardial metabolism in cardiac hypoxia. American Journal of Cardiology, 19, 385392.

Scottish Society of Physicians, Scientific Subcommittee (1964). Hydrocortisone in severe myocardial infarction. Lancet, 2, 785-786.

Shannon, A. D. and Courtice, F. C. (1975). The lysosomal enzyme $\mathrm{N}$-acetyl- $\beta$-glucosaminidase in rabbit muscle following a period of ischaemia. Pathology, 7, 25-33.

Shaw, R. F., Mosher, P., Ross, J., Jr., Joseph, J. I., and Lee, A. S. J. (1962). Physiologic principles of coronary perfusion. Journal of Thoracic and Cardiovascular Surgery, 44, 608-616.

Sonnenblick, E. H. (1962). Force-velocity relations in mammalian heart muscle. American Journal of Physiology, 202, 931-939.

Spath, J. A., Jr., Gorczynski, R. J., and Lefer, A. M. (1973). Possible mechanisms of the beneficial action of glucocorticoids in circulatory shcck. Surgery, Gynecology and Obstetrics, 137, 597-607.

Spath, J. A., Jr., Lane, D. L., and Lefer, A. M. (1974). Protective action of methylprednisolone on the myocardium during experimental myocardial ischemia in the cat. Circulation Research, 35, 4451.

Spath, J. A., Jr. and Lefer, A. M. (1975). Effects of dexamethasone on myccardial cells in the early phase of acute myocardial infarction. American Heart Journal, 90, 50-55.

Tecklenberg, P. L., Mullin, E. M., Stinson, E. B., and Morrow, A. G. (1973). The effects of massive doses of methylprednisolone on myocardial contractility and peripheral vascular resistance. A merican Heart Journal, 85, 216-226.

Toyama, M. and Reis, R. L. (1975). Effects of myocardial ischemia on ventricular compliance: protective role of hydrocortisone. Journal of Thoracic and Cardiovascular Surgery, 70, 458-465.

Tyers, G. F. O., Hughes, H. C., Jr., Todd, G. J., Williams, D. R., Andrews, E. J., Prophet, G. A., and Waldhausen, J. A. (1974). Protection from ischemic cardiac arrest by coronary perfusion with cold Ringer's lactate solution. Journal of Thoracic and Cardiovascular Surgery, 67, 411-418.

Vargish, T., Shircliffe, A., and James, P. M. (1974). Effect of steroids on cardiac function. American Surgeon, 40, 688-696.

Weisfeldt, M. L., Scully, H. E., Selden, R., Bello, A. G., Powell, W. J., Jr., and Daggett, W. M. (1973). Effect of mannitol on the performance of the isolated canine heart after fibrillatory arrest. Journal of Thoracic and Cardiovascular Surgery, 66, 290-299.

Weissmann, G. and Thomas, L. (1964). The effects of corticosteroids upon connective tissue and lysosomes. Recent Progress in Hormone Research, 20, 215-245.

Wiener, S. L., Wiener, R., Urivetzky, M., Shafer, S., Isenberg, H. D., Janov, C., and Meilman, E. (1975). The mechanism of action of a single dose of methylprednisolone on acute inflammation in vivo. Journal of Clinical Investigation, 56, 679-689.

Wildenthal, K., Crie, J. S., and Vastagh, G. F. (1973). Cardiovascular function and survival during severe systemic hypoxaemia: influence of glucosepotassium-insulin solution and of beta-blockade. Cardiovascular Research, 7, 174-180.

Willman, V. L. and Barner, H. B. (1969). Anatomical and physiological considerations in cardiac preservation. Cryobiology, 5, 413-422.

Wilson, J. W. (1974). Cellular localisation of ${ }^{3} \mathrm{H}-$ labeled corticosteroids by electron microscopic autoradiography after hemorrhagic shock. In Steroids and Shock, edited by T. M. Glenn, pp. 275299. University Park Press, Baltimore.

Wisheart, J. D. (1975). Myocardial function following cardiopulmonary bypass. Annals of the Royal College of Surgeons of England, 57, 74-85.

Requests for reprints to: A. Hedley Brown, MS, FRCS, Wellington Hospital (Private Bag), Riddiford Street, Newtown, Wellington 2, New Zealand. 